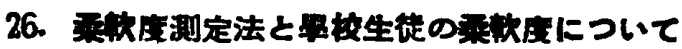

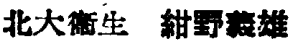

中學校・高等學校生徒の柔軟度を，紺野式柔軟 传計を用いて測定した。，

1. 紺野式柔軟度計の使用法につけてのべる

2. 測定の結果，男女別，年齡別化につ、て のベる

3. 湘定俚，前屈柔軟・後屈柔顿・左右側屈及 び開脚度につけて行つた。

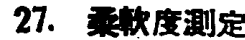

\section{京都大學体青研究室 山岡斯一・木夜一生・} 石山平作

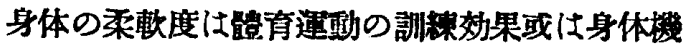

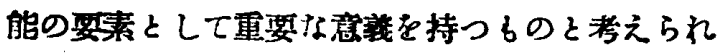
ろ.ころに余等は新的しく柔㜞度測定機を考案し，

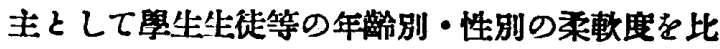
洨・湘定した。これに上れば，學徒の前屈・後屈

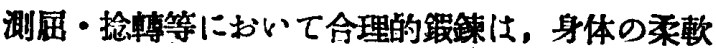
度に的て有効な作用を與えることを知つたので ここに骤する。

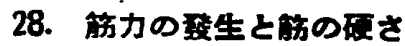

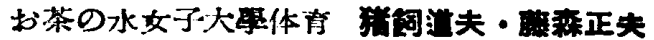 上野高校 石井}

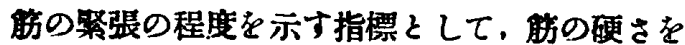
測定した，时を直角に屈曲した装熱で，手にェル エメーターのひもを持ち、最大に努力しているを

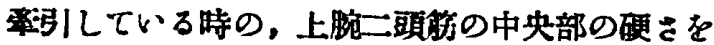

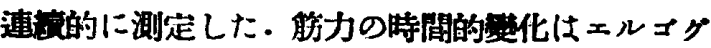
ラフに記銭された。最大の努力を持精しているに

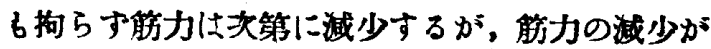

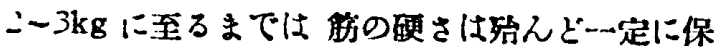
たれた。これに對してェルゴーーターの代りに順 夷に荷重を增加する方法をとると，館の硬さは荷 重の大きさにつれて增加するが，一定の荷重以上 では筋の硬さが仼ば一定となることが見られた。

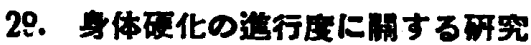

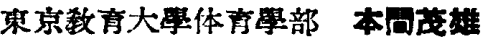

脚の前後左右開，体の側屈，体の前屈，体の㘼 屈につき采軟指数を算出し，身体硬化の進行度を 年漓別に調へたをころ概れ头の如き傾向のあるこ そを觀取した。

1. 若、程身体が采く、入十䏩後になると不自 然な程硬くなっていることが目立つ。

2. 何孔運動をしはいるのは比较的速かに身体 が硬くなる。

3. 老年になり,淂居して 身鹃を動かさないで いると急速に身体の柔㜞性を失う。

4. 一身体の硬化度は，特別の運動を行はない者 に於いては，邀年一定の比率を以て進行する。

5. 幼兒に於てる，放任して膡くを，身体は逐 年硬化して行くが，所謂柔軟体操存每日合劍に行

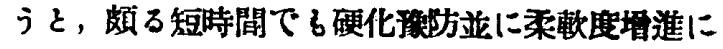
著しい効果があけられる。

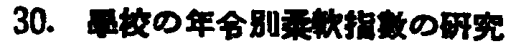

\section{東京数育大雪体育部 本間成雄}

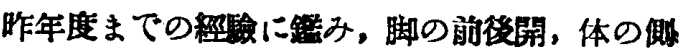

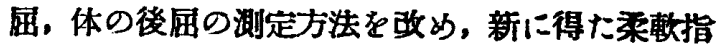
数に開し左の如胥報告をする。

1 湘定方法の基潅に就いて

- 年缷別柔軟指数の分布狀況の報告

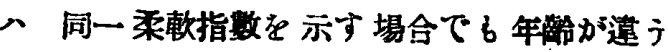
と同一柔軟度を示さはいと考えるべである。よ つて，年数别に軟(上)・並(中) ・硬(下) の三類 ・に分かち，更にこれを，上の上・上・上の下・中 の上・中・中の下・下の上・下・下の下の九段㳻 に評別を試みた結果に就いて報告する。

\section{1.、幼兒の振力測定法の校讨}

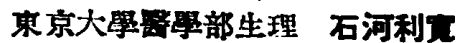

幼稚園及び小孟校低學年の兒童の揘力は從來の

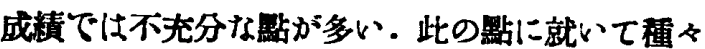
の考察を加えてみた。

1. 目盛の誤差一挃力計は祭のために3〜4 kg の負荷を與えなけれは指針が動かない。しか るに目盛は必す雺から刻えであるので，提力が 